International Journal of Engineering \& Technology, $7(4.38)(2018)$ 597-602
International Journal of Engineering \& Technology
SPC
Website: www.sciencepubco.com/index.php/IJET
Research paper

\title{
Using the Scenarios of Simulation Case Assignments in the Educational Process of Students in the Specialty "State and Municipal Management", Master's Degree Programme
}

\author{
Olga Urzha $^{1}{ }^{*}$, Valentina Kataeva ${ }^{1}$, Tatiana Evstratova ${ }^{1}$, Valentina Zhukova ${ }^{2}$, Irina YIlina ${ }^{1}$ \\ ${ }^{I}$ Russian State Social University, 4,1, V.Pika, Moscow, 129226, Russia \\ ${ }^{2}$ Ural Federal University, 51, Lenina ave., r. 262, Ekaterinburg, 620000, Russia \\ *Corresponding author E-mail: urzha.o@mail.ru
}

\begin{abstract}
The article is devoted to the use of simulation case assignments in the learning process of students pursuing a Master's degree in "State and Municipal Management" at Russian State Social University. This university was established in 1991 for the high-quality training of specialists in the social sphere. The specialty "State and Municipal Management" enables students to explore the theoretical and practical levels, the essence and features of management interactions in the system of state and municipal administration, the main objectives, tasks and mechanisms of governance at the state and municipal levels, the methods and means of attracting investments in the economy of the municipality and the region, the features of the management system of the asset portfolio. The discipline "Sociology of Management" is the base for the direction of training "State and Municipal Management". The knowledge and skills acquired during the study contribute to a better understanding of the social, political, and economic patterns of management processes. Management sociology is a science which summarizes all management sciences in terms of targeting and special study of the patterns of managerial relations at all levels of society and its elements' functioning, as well as in all subject areas, the spheres of activity in society. The study of sociology as a science about relationships in the process of governance, connections, and interactions of the subjects of management activity in Russia has started relatively recently. In the mid-1990s, scientific readings and conferences were focused on the definition of the substantive field of science, its structure.

Over these years, the situation has been as follows. The sociologists who violently debated and developed this scientific direction, after the appearance of the specialty "Management in Social Sphere" in 1996, in 1999- the specialty "State and Municipal Management", and in 2002 - the specialty "Personnel Management", handed the study of this discipline to managers. And all of these management specialties found themselves in the consolidated group of professions "Economics and Management". This greatly affected the gap in the subject field of management itself. Most economists imagined that management is economics. The lawyers of those universities where departments of "Public Administration and Legal Support" were established never doubted that management is a legal sphere of activity. None of them paid special attention to the sociological component. However, those universities, which in the course of training in the field of state and municipal government created departments of sociology management in their structure or modules in the curricula, provide the most high-quality preparation of future managers.
\end{abstract}

Keywords: Case assignments, simulation cases, state and municipal management, training of students, educational process.

\section{Introduction}

Knowledge management is becoming an important tool for enhancing the effectiveness of the activities of students and graduate students of higher education institutions through the systematic exchange of experiences, ideas, and information. The formation of the fifth technological mode in Russia sets for the system of higher vocational education the goal of developing students' abilities and skills of project management in information civilization. Given that the youth acts as a social group with specific age and psychological characteristics and performs a crucial social function of social reproduction, it must be directly involved in the administration of the state, region, and municipality. On the one hand, this will facilitate the integration of the younger generation in social relationships, the representation of their interests at the national level. On the other hand, it will help create a new generation of managers of the most talented and proactive young people and, thereby, ensure continuity in the policy and management spheres [20, 22].

Modern society "is on the transition from information civilization to the civilization of intelligence. Peter Drucker in the 1950s first used the term "knowledge society", correctly predicting that innovation and knowledge will become a double-engine of the new economy".

In the development of modern civilization, a person's ability to study and comprehension of reality have reached a new level. More and more people become participants in the cognitive process that affects educational structures. Today they are required not just to transfer knowledge. The legitimate demands are imposed on them concerning the use of information technologies to promote the processes of self-development and selforganization of learners $[1,19]$.

In order to effectively manage, one must know exactly all the features of the control object. Social systems as control objects are all social groups. It is, therefore, necessary to teach students to recognize the theoretical and methodological features of social 
groups with different case assignments. Unfortunately, absolutely unscientific concepts such as "people", "masses" have been propagated in Russian society for long decades, but they had a great political value for the formation of the notion that society is homogeneous and impersonal. The slogan of the Soviet period was "The people and the party are united". Sociology has been forbidden in Russia for decades precisely because of its key topics - "social stratification", "social mobility", "social groups" that proved the heterogeneity of society, and hence the need for the development of socially-oriented management, sociology of management [21].

A great contribution to the development of the sociological theory of groups was made by the sociologists of the late 19th - early 20th centuries - E. Durkheim. G. Tarde, L. Gumplowicz, Ch. Cooley, F. Tönnies, etc. So, the Austrian sociologist L. Gumplowicz believed that "in sociology units, elements are social groups... Sociology cannot be built on the relationship of individuals to each other, and the nature of the group cannot be comprehended from the nature of the individuals" . G. Simmel, the famous founder of the formal school in sociology, saw a group as a form of social interaction [15]. The French sociologist E. Durkheim believed that a group is an independent element of social reality [2].

In modern sociology, the approach to the study of society is built on the recognition of the importance of all social groups, since the difference in their situation leads to different interests, the harmonization of which is the foundation for social policy, social control as a means of implementing social policies.

To ensure that a student becomes a real manager, it is necessary to form in him/her the awareness that for effective management, building management relations in society he/she needs not only the knowledge of the general theory of social groups but also a profound study of the theory of small groups [3]. Virtually all social organizations are small groups; therefore, for effective management, it is needed to know the features, specifics of small groups. One of the founders of microsociology Jacob Moreno wrote: "Instead of analyzing social classes consisting of millions of people, we are engaged in a careful analysis of small groups. This is a derogation from the social system to its atomic structure" $[10,11,23]$.

It is the study of the specificities of small groups in the 1930s in America and in the $1940 \mathrm{~s}$ in Europe that contributed to the efficient solution of administrative problems. This was due to the need for scientific analysis of social problems such as improving productivity, strengthening the family, upbringing of children, eradication of interpersonal conflicts, crime prevention, etc. It is known that at this time the theories of "scientific management", "group dynamics", "group therapy", "sociometry" and others appeared in the United States. Under the orders of the military departments, monopolies, and the government, the studies of small groups were carried out, related to the issues of "social stratification", "human relations" in the industry, morale in the army, the effectiveness of propaganda, racial and ethnic conflicts, the situation of the family, child-rearing, etc. A great contribution to the study of the small social groups was made by the American sociologist Mills [9].

The flexibility and mobility of a modern specialist in state and municipal management depend directly on the innovational approach to educational activities. A teacher, with fundamental knowledge who mastered modern methods of teaching, by using case assignments in pedagogical activity enhances the level and quality of impact on students' space at all levels of interaction: from interpersonal to educational. This process creates the conditions for the innovation development of educational institutions and increasing the quality of training of specialists [4]. Sociology of management makes it possible, on the basis of methods for analyzing the characteristics of the subject of management relations, the socio-engineering approach in learning object management, to develop and propose the most appropriate subject-object relationship to ensure the maximum effectiveness of management in all sectors of the economy, in particular, socially significant sectors of the economy, for example, housing and utilities services; the financial sector, for example, the banking sector, etc. $[8,24]$.

\section{Methods}

The authors of the article, while conducting practical classes with students in the training direction "State and Municipal Management", Master's degree level, have actively used the incident method. The feature of this method is that a learner finds information for decision-making by himself/herself. Students receive a briefing on the case. For decision-making, the information available is clearly inadequate, so a student must collect and analyze information necessary for decision-making. Since this requires time, the independent homework of students is possible. At the first stage, students get a message and questions to it $[6,12]$.

The situational analysis method was also used. It is the most common method since it allows exploring difficult situations deeply and thoroughly. Students are given a text with a detailed description of the situation and a task requiring a decision. The text can describe the already taken actions and decisions made, for students to assess their feasibility $[6,12]$.

It is obvious that any technologization of the social space and administrative relations in particular, begins with the receipt of necessary information about the state, processes and laws of the system's functioning. In this case, socio-engineering methods become crucial [21].

The authors in their pedagogical activity, to successfully educate students, apply the systematic analysis method "8 wheels" by Tikhomirov that helps to achieve an in-depth understanding of both the subject and the object of administrative relations, based on the complexity and the diversity of their typology and characteristics of the system approach to the analysis of their conformity. This technique was introduced in the late 1990s by a scientist from Russia, Doctor of Technical Sciences, Professor Vladislav Borisovich Tikhomirov, who returned after a long business trip to the United States, where he was one of the leaders of the UNITAR - international United Nations Institute for Training and Research. Abroad, Tikhomirov had a chance to expand his knowledge about political analysis, participated in solving practical tasks to resolve conflicts, including in the area of inter-ethnic relations, mastered many unique methodologies, which were not known in Russia [17]

\section{Literature Review}

According to Petruk and Kulinka, "A WebQuest is a didactic structure within which the search activities of students are formed; it sets the parameters of this activity and determines its time limits. This changes the function of a teacher, who periodically creates necessary conditions when students turn from passive objects of training activities into its active subjects. In fact, a WebQuest is an interactive process in which students demonstrate the motivation to acquire the necessary knowledge" [13].

The activity of control subjects to a greater extent relates to the development of conceptual approaches, global vision of the ways of implementation of the tasks arising from specific management objectives - the development of society. Their effectiveness depends largely on the in-depth study of the actual state of the society and its members. It largely determines the functions of the control subjects, and, therefore, imposes specific requirements for their structure and quality. Science and practice of social development proved wrong both the point of view that the conceptual development of the society can be carried out by one person and the point of view that management may be carried out by the majority. In this regard, one can recall the well-known 
words by G. Spencer that it is wrong to believe in the existence of "all-powerful" despots", since "... power is the sense of community, acting through an intermediary that is formally or informally set. As practice shows, the private will of despots is an insignificant factor; its influence is proportional to the degree of expression of the will of the rest" [16]. However, Bryce, studying the subject of power in a democratic society, in his work "Modern Democracy" in 1921 came to the conclusion that the percentage of people who get really close to the implementation of power is extremely small and the control inevitably passes into the hands of the minority. He said: "... so few are actually the people who run the world".

Proceeding from this, one can once again highlight the importance of the training of management personnel. Sorokin wrote: "Anyone doing the reconstruction of society should pay particular attention to the problem of proper reorganization ... of institutions. ... If they are defective ... so no social improvement would bring prolonged and profound changes. Ultimately, history is made by people. People occupying positions, which they do not conform to, can "successfully" destroy society, but cannot create anything of value, and vice versa" [16].

\section{Results}

\subsection{Problem Statement and the Results of the Study}

The authors hypothesized that the use of simulation case assignments in the educational process provides students with information competence, knowledge and skills, the ways of information activities, which they will need in the future, develops the ability to organize and synthesize information, to put forward innovative ideas and non-standard approaches to their implementation.

Since 1998, full-time students have been asked to perform a job based on the method of system analysis "8 Wheels" by Tikhomirov. Students must examine a text of an election program of parliamentary candidates or political parties, text of a report as a system, reduce it to its components, and then based on the content analysis of each part make an evaluation of the whole, to which extent the text is systematically developed. After this analysis, it becomes obvious that there is a problem in the system (text, event), reaffirming the importance of the systematic approach in solving any task [17].

This technique originated thousands of years ago, when priests taught politicians about the past, comparing the social system to a chariot, and the leadership was assessed on its ability to manage it. Let us consider the structural logical model of the social system "Eight Wheels" (Table 1). It is not contrary to the known Marxist theoretical view of society in which the productive forces and social relations stand out.

Table 1: The structural logical model of the social system - "Eight Wheels"

\begin{tabular}{|c|c|c|c|c|}
\hline $\begin{array}{l}\text { N } \\
\text { N } \\
\text { II } \\
Z \\
n \\
D \\
0 \\
U \\
U \\
n \\
Z \\
0 \\
0\end{array}$ & $\begin{array}{c}2 . \\
\text { CONSCIOUSNE } \\
\text { SS } \\
\text { beliefs } \\
\text { (worldview) } \\
\text { knowledge } \\
\text { (education) } \\
\text { experience } \\
\text { cultural } \\
\text { heritage } \\
\text { psychology }\end{array}$ & $\begin{array}{l}\text { 4. QUALITY } \\
\text { science } \\
\text { information } \\
\text { time }\end{array}$ & $\begin{array}{c}6 . \\
\text { HARMONIZATI } \\
\text { ON } \\
\text { leadership } \\
\text { political } \\
\text { apparatus } \\
\text { control } \\
\text { legal culture } \\
\text { moral } \\
\text { culture } \\
\text { value system }\end{array}$ & $\begin{array}{c}8 . \\
\text { ORDER } \\
\text { manageme } \\
\text { nt } \\
\text { economic } \\
\\
\text { mechanis } \\
\mathrm{m} \\
\text { accountin } \\
\mathrm{g} \\
\text { planning } \\
\text { economic } \\
\text { culture } \\
\text { economic } \\
\text { standards }\end{array}$ \\
\hline & \\
\hline
\end{tabular}

\begin{tabular}{|c|c|c|c|c|}
\hline 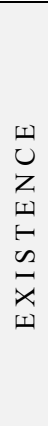 & $\begin{array}{l}\text { skills } \\
\text { needs } \\
\text { health } \\
\text { number } \\
\text { parties } \\
\text { involved in the } \\
\text { events }\end{array}$ & $\begin{array}{c}\text { means } \\
\text { of } \\
\text { production } \\
\text { property, } \\
\text { clothes } \\
\text { accommodati } \\
\text { on } \\
\text { food } \\
\text { territory } \\
\text { (space) } \\
\text { 3. TO HAVE }\end{array}$ & $\begin{array}{l}\text { services } \\
\text { political } \\
\text { social } \\
\text { religious } \\
\text { ethnic } \\
\text { family } \\
\text { security } \\
\text { operation } \\
\\
5 . \text { TO } \\
\text { EACH } \\
\text { OTHER }\end{array}$ & $\begin{array}{l}\text { production } \\
\text { exchange } \\
\text { distribution } \\
\text { consumption } \\
\text { property } \\
\text { protection of the } \\
\text { environment }\end{array}$ \\
\hline & \multicolumn{2}{|c|}{ F O R C E S (ELEMENTS) } & \multicolumn{2}{|c|}{ R E L A T I O N S (LINKS) } \\
\hline
\end{tabular}

This system assumes that people should "be" in it (as a part of the productive forces), characterized by number, health, abilities, etc. - "wheel" No. 1. These parties involved should "have" a certain material and technical base (as the second part of productive forces), which includes the territory, means of production, accommodation, clothes, etc. - "wheel" No. 3. Social relations reflect the relationships of people with each other that are reflected in "wheel" No. 5. The attitude towards what they have is reflected in "wheel" No. 7. These are the four components of the social system that should be considered by a manager who really wants to know the society and to manage effectively.

The system not only exists but also strives for the best quality. Therefore, each component corresponds to a certain goal. So, the desire "to be" is focused on life expectancy and harmonious development of each person: to "be" better means to be more conscious, to have the necessary common culture, experience, knowledge, and beliefs - "wheel" No. 2. The desire "to have" assumes ensuring the material well-being and necessary economic growth, better quality that is largely determined by science, information, etc. - "wheel" No. 4. The development of people's relationships to each other is related to the existence of the relevant relations in the society, the harmonization of relations, sound management - "wheel" No. 6. But the development of people's attitude towards what they have is aimed at ensuring the conditions that allow producing, distributing and consuming prudently, increasing greatly the things available, and professional management, planning, accounting, high economic culture contribute to it - "wheel" No. 8.

Achieving the objectives of social development requires a certain level of culture. Thus, our four components appear to have qualitative characteristics, as if they are doubled. Hence the model has eight "wheels".

Priests compared the system to a chariot. For the chariot to move evenly, the front wheels should not run away from the back ones. According to the authors' opinion, industrial relations should not lag behind the productive forces. For the stability of motion, it is necessary for all the wheels to be the same size and to spin in sync. In this model, this means that all components of the social system should develop interconnectedly and proportionately. One cannot go steadily on one wheel. Unfortunately, in Russia, people have been focused for many years only on "owning and possessing more". Not surprisingly, Russian "chariot" was on the point of overturning. Or, what happens if one wheel, for example, the front right is big, and the other, for example, the rear left is small? Such chariot will not go forward and will be spinning on the spot. This, in Russian society, is similar to the situation of "stagnation". This happened because all the attention was focused on "having" (more oil, tractors, grain, shoes), forgetting about the "wheel" of reasonable attitude to what is produced, about its host [17].

The model of "eight wheels" allows analyzing what impacts a particular process in society - technological changes, the emergence of new needs, the reorganization of the state apparatus or reorientation of mass consciousness - as it clearly illustrates the relationship of these phenomena. Using this technique it is possible to plan the development and to analyze the causes of the 
crisis, destruction of the system. In this case, the "wheels" are considered as "windows of vulnerability". They provide correlation of all events and processes in society, answer the question about the causes of crises, internal conflicts and struggles in society.

A systematic approach to building management relations presupposes the absolute knowledge of the characteristics and specificity of both the subject and object of management. Building management relations at all levels and in all spheres of society depends largely on the management style of the subject of administrative relations.

Here is another example of the use of simulation cases in the educational process. A WebQuest of a humanitarian character on the topic "The History of Project Management" [13] was developed so that everyone in an interactive way can learn the history of project management from the position of one of the roles that will be chosen by the participant himself/herself. "In the classic sense, a WebQuest is a problematic task with the elements of a role-playing game (RPG), for which the Internet resources are used. As noted by Schmidt: "WebQuests are mini-projects based on the search for information on the Internet" [7, 14].

A brief description of the WebQuest that received the seconddegree diploma in the framework of the 1st All-Russian Contest of Educational WebQuests "Scientific Search" on May 27, 2017 is presented in this article.

Why is it important to know the history of project management?

The answer lies on the surface: to avoid the mistakes already committed. By studying both domestic and foreign experience, one will be able to adapt flexibly to unusual situations. Therefore, the main task here will be a comprehensive study of project management history.

Currently, not enough attention is paid to the study of project management history. It happens so that this topic is dealt with too superficially, and as a result, students do not get the full picture, do not see cause-effect relationships, and cannot use the experience and solutions that have already been taken in the past. If to consider project management only from the perspective of theoretical approaches, it will not give the full picture, it will not be clear what the prerequisites for the formation of one or the other approach are. Only by studying history, one can assess and analyze the direction of project management. It is also important to share both the national history of project management and the history of project management in Western countries, as it is very important to consider the specifics of management in Russia and abroad. For all of the above reasons, a WebQuest was developed to explore the history of the project management development.

Our WebQuest aims at achieving the following goals:

-to show the importance of knowledge of project management history;

-to show the differences in the formation of project management in Russia and abroad;

-to help assess the current situation in project management; - to predict the vector of development of project management.

To implement the set goals, a role-playing WebQuest was compiled. As the topic concerns project management, it is important to understand that the project always involved the project teams. Therefore, a group of five people is needed to pass this quest, where each participant will choose a role as desired. The success of the passing and development of the quest depends on how faithfully each of the participants will relate to their role.

There are five of them to choose from, namely:

- Historian

- Practitioner

-Forecaster

- Analyst

- Designer

If one of the participants in the WebQuest chooses the role of a "Historian", he/she collects information about the general history of project management. He/she will need to characterize the modern development stages of project management.
The second role the party can take is a "Practitioner". He/she needs to consider the formation of project management in Russia, its importance and role.

The third role of the quest is a "Forecaster". He/she should examine modern trends in the development of project management both in Russia and in other countries.

The fourth role is an "Analyst". He/she needs to collect the information from the Historian, Practitioner, and Forecaster, to summarize it, analyze and draw conclusions.

The last role of the quest is a "Designer". He/she needs to organize the data collected from Analyst briefly, colorfully and logically, to make a presentation in PowerPoint.

It is important to understand that the participants in the web-quest should work as a coordinated team. If they don't, it will be more difficult to complete it.

For the successful completion of this WebQuest, the next steps of its implementation were developed:

1. The Historian and the Practitioner work in parallel, investigating necessary information, and then transmit it to the Practitioner.

2. The Practitioner, using the information and resources, explores his/her subject.

3. The Historian, Practitioner, and Forecaster transmit the received information to the Analyst.

4. The Analyst with the help of the Historian, Practitioner, and Forecaster sorts out the resulting investigation and perform his/her role tasks, transmits the information fully prepared to design to the Designer.

5. The Designer performs his/her role-playing tasks.

6. After the task is accomplished, all information is provided in the form of a PowerPoint presentation to the participants.

The evaluation criteria of WebQuest successful completion: - a clear and concise formulation of the basic ideas and proofs; -the completeness of topic disclosure;

- the accuracy of performance;

-the execution of all the role-playing challenges;

- the availability of drawings, diagrams, tables (if necessary);

- a well-prepared presentation (report).

Thus, following all the above-mentioned points and rules, the participants easily and successfully complete the WebQuest and will be able to understand the history of project management, demonstrate an interest in the topic of project management and will feel familiar with it at the initial stage of studying this discipline.

For successful training in the specialty "State and Municipal Management", students need to cultivate the ability to analyze, plan and organize professional activities. Young people, due to the fact that they are in the process of development (social, psychological, and ideological), to a greater extent than other age groups, are subject to different influences, they respond to them more directly and actively.

\section{Discussion}

Thus, the use of situational case-quests in the educational process allows reducing the gap between theoretical knowledge and practical skills. Students get the experience of practical application of the theoretical foundations and the ability to work in a team. The survey was conducted of the full-time students of the specialty "State and Municipal Management" on the topic "The opinion of the students of the Russian State Social University, of the management faculty about the benefits of case methods". The empirical research was conducted from March 5 to April 15, 2018, at the Faculty of Management. The study included 345 students aged 22 to 24 years.

The research results are shown graphically in Figure 1. 


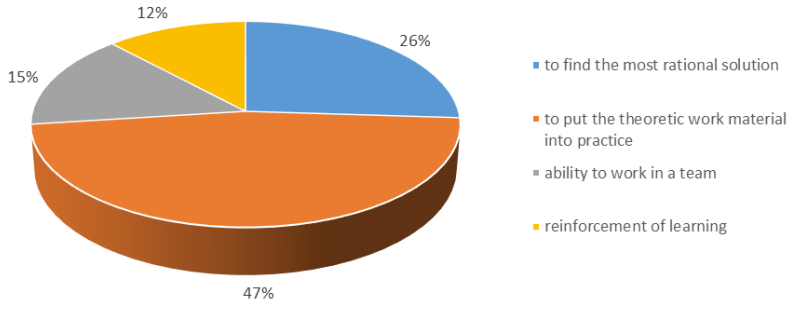

Fig. 1: The opinions of the students of management faculty about the benefits of case methods in the educational process

Second, the academic performance of students of the Faculty of Management in the disciplines with the use of simulation and case assignments was compared with the performance in disciplines with the traditional methods of learning. As can be seen from Figure 2, qualitative performance is higher in those students who systematically solve simulation cases assignment on the disciplines they are taught.

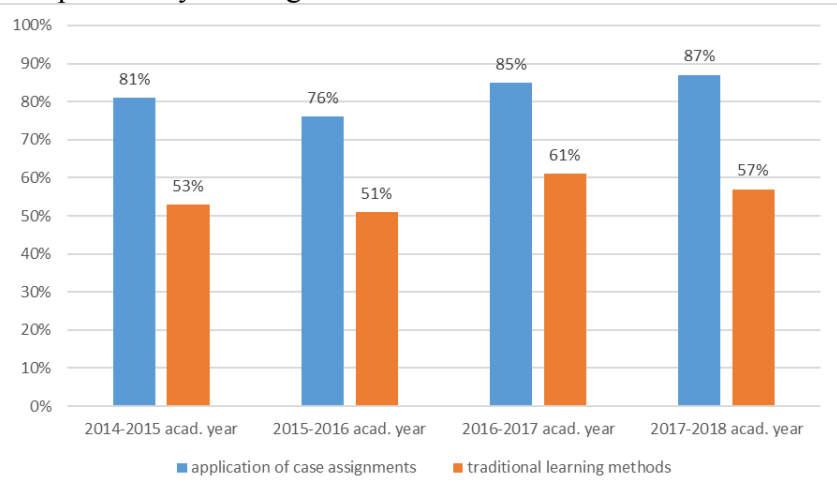

Fig. 2: The comparison of the academic progress of students of the Faculty of Management of the Russian State Social University in the disciplines with the application of case assignments and in subjects with traditional learning methods

\section{Conclusion}

Thus, the experience with the use of case assignments as a way of interactive learning for students pursuing a Master's degree in the specialty "State and Municipal Management" at the Faculty of Management of the Russian State Social University showed that this method contributes to the improvement of the quality of students' preparation owing to the fact that thinking processes are actively involved in the development of knowledge, the situation analysis ability develops, the alternatives are assessed, and the best possible solutions of tasks are selected. Using theoretical knowledge, students can analyze and evaluate phenomena that are necessary for professional activity. The case method promotes the formation of a sustainable skill for solving practical problems.

Today, case studies have gained a leading position in education, are actively used in the domestic and foreign practice of education and are considered one of the most effective ways of teaching students of problem-solving skills.

It is proposed through the knowledge of the socio-psychological, ethnocultural and confessional features of the youth as a sociallydemographic group of the modern society to stimulate the social activity of young people, involve them in the activities of local authorities. In Russia, the problem of stimulating the activity of young citizens in solving local issues is particularly urgent and needs to be tackled. Today, there is a deep contradiction between the intellectual innovative potential, which each local community has, and the level of its use in different types of work, particularly managerial that does not tolerate the routine and stagnation, and requires constant renewal, making imaginative decisions. The solution to this problem is of great theoretical and practical importance for the need to maintain the spirit of creative community atmosphere, sharing new ideas and identifying ways of its development, where special attention should be paid to improving municipal personnel policy, working with senior staff, assessing their professionalism, motivation system and training of innovative technology development. For this purpose, the following simulation cases are applied in training:

1. One must develop a plan (program) of a youth social project aimed at solving social problems (tasks). Determine the relevance, purpose, objectives, and main actors of the project management process, and the temporal characteristics of the project, the work content of the project, the economic component and the specifics of financing and the specific expertise of projects and other components.

2. Select one of the directions of the social sphere (ecological, socio-cultural, military-patriotic, civil, sports, etc.). Analyze the activity of public youth organizations in an area in this direction. What are their relevance and effectiveness? Develop a business plan for any youth organization, which would be interesting for young people in the area.

3. To change this situation and more actively involve the youth resources in the functioning of the Russian companies on longterm prospects, formulate proposals for the modernization of technologies for the implementation of the youth policy in the Russian Federation.

\section{References}

[1] Apanasyuk LA, Egorova EN, Kryukova EM, Mosalev AI \& Mukhomorova IV (2017), Socio-Ecological Education as a Factor of Economic Development. In SGEM International

Multidisciplinary Scientific Conference on Social sciences and Art 1, Vol. 3, 971-978.

[2] Durkheim E (1912), Samoubiistvo. Sotsiologicheskii etyud [Suicide. A Study in Sociology]. St. Petersburg, 399.

[3] Evstratova TA (2017), Osnovy molodezhnoi politiki [The Fundamentals of Youth Policy]. Moscow; Berlin.

[4] Golovanova YuV (2017), Innovatsionnyi podkhod k obucheniyu pri ispolzovanii metoda keisov [An Innovative Approach to Learning by Using the Case Method]. Molodoi uchenyi, 21, 415-418. Availabla online https://moluch.ru/archive/155/43899/

[5] Gumplowicz L (1899), Osnovy sotsiologii [The Fundamentals of Sociology]. St. Petersburg, 368.

[6] Ilina I, Kryukova E, Potekhina E, Shadskaya I \& Abyzova E (2017), Russian Lectures at the Crossroads of Reforms: Strategies of Survival and Adaptation. European Research Studies Journal, 20(2), 86-97.

[7] Katayeva VI (2017), Opyt prepodavaniya upravlencheskikh distsiplin $\mathrm{s}$ ispolzovaniem veb-kvest tekhnologii $\mathrm{v}$ sisteme vysshego professionalnogo obrazovaniya [The Experience of Management Subjects Teaching with the Use of WebQuest Technologies in the Higher Professional Education System]. In Sovremennye obrazovatelnye Web-tekhnologii v sisteme shkolnoi i professionalnoi podgotovki. Mezhdunarodnaya nauchnoprakticheskaya konferentsiya. National Research Lobachevsky State University of Nizhny Novgorod, Arzamas Branch, 421-424.

[8] Kryukova EM, Makeeva DR, Atamanova MA \& Shadskaya IG (2013), Financial Mechanism of Housing and Utilities Infrastructure. Life Science Journal, 10(4), 790-794. Available online http://www.lifesciencesite.com/lsj/life1004/099 21206life1004 79 0 794.pdf

[9] Mills TM (1972), O sotsiologii malykh grupp [On the Sociology of Small Groups]. In Amerikanskaya sotsiologiya: Perspektivy, problemy, metody. Moscow.

[10] Mironova OI, Pluzhnikova NI, Akimova NN, Nekrasova MV, Shagayeva EA \& Zhukova VI (2014), Social and Psychological Factors of the Compelled Choice of Profession. Journal of Advanced Research in Law and Economics, 5(2), 147-156.

[11] Moreno JL (1958), Sotsiometriya [Sociometry]. Moscow. 
[12] Nakhratova EE, Ilina IY, Zotova AI, Urzha OA \& Starostenkov NV (2017), The Analysis of the Relevance of Educational Programs for Applicants and the Labor Market. European Research Studies Journal, 20(3), 649-659.

[13] Petruk MV \& Kulinka YuS (2014), Veb-kvest kak sredstvo razvitiya navykov informatsionnoi deyatelnosti na urokakh tekhnologii [WebQuest as a Means of Developing Skills of Information Activities in Technological Classes]. In Molodezhnyi nauchnyi forum: Gumanitarnye nauki: Elektronnyi sbornik statei po materialam XI studencheskoi mezhdunarodnoi zaochnoi nauchno-prakticheskoi konferentsii, Moscow: Moscow Center for Continuous Mathematical Education.4(11). Available online https://nauchforum.ru/archive/MNF humanities/4(11).pdf

[14] Schmidt WV (2010), Tekhnologiya veb-kvesta pri navchanni angliiskoi movi studentiv nemovnikh spetsialnostei [WebQuest Technology in Teaching English to the Students of Nonlinguistic Specialties]. Available online http://winner.seua.net/page26/1/10/

[15] Simmel G (1909), Sotsialnaya differentsiatsiya [On Social Differentiation]. Moscow.

[16] Sorokin PA (1992), Chelovek. Tsivilizatsiya. Obshchestvo [Human. Civilization. Society]. Moscow: Politizdat.

[17] Tikhomirov VB \& Tikhomirova IV (1992), Politicheskaya obstanovka v strane $i$ vokrug nee [The Political Situation in and around the Country]. Moscow: Publishing House of the Plekhanov Russian Academy of Economics.

[18] Urzha OA (2007), Sotsialnaya inzheneriya kak metodologiya upravlencheskoi deyatelnosti [Social Engineering as a Methodology of Management Activities]. Sotsiologicheskie issledovaniya, 10, $87-$ 96.

[19] Urzha OA (2016), Rol sotsiologii upravleniya v povyshenii effektivnosti gosudarstvennogo i munitsipalnogo upravleniya [The Role of Management Sociology in Improving the Efficiency of State and Municipal Management]. In Diagnostika vlasti $i$ upravlenie: kommunikativnye mekhanizmy i "Dvoinye standarty". Materialy Vserossiiskoi konferentsii s mezhdunarodnym uchastiem XV Dridzevskie chteniya. Moscow, 55-61.

[20] Urzha OA (2016), Sotsiologiya upravleniya kak instrument effektivnogo sotsialnogo upravleniya [Sociology of Governance as a Means of Effective Administration]. Sotsialnaya politika $i$ sotsiologiya, 15, 2(115), 163-171.

[21] Urzha OA (2017), Sotsialnaya inzheneriya kak metodologiya upravlencheskoi deyatelnosti [Social Engineering as Methodology of Management Activity]. Sotsiologicheskiye issledovaniya, 10, 8796. Available online https://www.libnauka.ru/item.php?doi=10.7868/S01321625171000 99

[22] Urzha OA (2018), Sotsiologiya upravleniya: uchebnoe posobie dlya magistratury $i$ aspirantury [Sociology of Management: Textbook for Graduate and Post-Graduate Education]. Moscow.

[23] Vinichenko MV, Frolova EV, Kabanova EE, Kozyrev MS \& Evstratova TA (2016), The Youth Employment Problems. Journal of Advanced Research in Law and Economics, 7(2), 378-387.

[24] Zaernjuk VM, Kryukova EM, Bokareva EV \& Chernikova LI (2014), The Study of Theoretical Approaches, Banking Financial Intermediation and Directions of Its Development in Russia and Abroad. World Applied Sciences Journal, 30(12), 1746-1748. doi: 10.5829/idosi.wasj.2014.30.12.14252 